\title{
A Critical Research Agenda for Wills, Trusts and Estates
}

\author{
By Bridget J. Crawford and Anthony C. Infanti
}

\begin{abstract}
The law of wills, trusts, and estates could benefit from consideration of its development and impact on people of color; women of all colors; lesbian, gay, bisexual, and transgendered individuals; low-income and poor individuals; the disabled; and nontraditional families. One can measure the law's commitment to justice and equality by understanding the impact on these historically disempowered groups of the laws of intestacy, spousal rights, child protection, will formalities, will contests, and will construction; the creation, operation and construction of trusts; fiduciary administration; creditors' rights; asset protection; nonprobate transfers; planning for incapacity and death; and wealth transfer taxation. This essay reviews examples of what the authors call "critical trusts and estates scholarship" and identifies additional avenues of inquiry that might be fruitfully pursued by other scholars who are interested in bringing an "outsider" perspective to their work in this area.
\end{abstract}

\section{INTRODUCTION}

A parent may be critical of a teenager's revealing outfit. A novel may experience critical success. The bookstore may carry a critical edition of Shakespeare's sonnets. A particular task may be critical to a mission. The word "critical" has multiple meanings. As we consider the outlines of a "critical" research agenda for wills, trusts and estates, it is important to clarify what we mean by the term. If one understands "critical" to mean judgmental, often in a negative sense, then a critical research agenda may be nothing special. After all, a legal scholar's stock in trade is identifying a particular law's shortcomings and proposing remedies to cure its defects. Similarly if "critical" refers to the judgment of a group of evaluators, any trusts and estates scholarship might meet critical acclaim, garner mixed reviews, or face critical oblivion when it is ignored altogether. Or, a "critical" collection of scholarship might be akin to an anthology or compilation of all important academic work on a

- Bridget J. Crawford is a Professor of Law at Pace University School of Law. B.A. Yale University. J.D. University of Pennsylvania Law School.

- Anthony C. Infanti is a Professor of Law and the Associate Dean for Academic Affairs at the University of Pittsburgh School of Law. B.A. Drew University. J.D. University of California, Boalt Hall School of Law. LL.M. in Taxation, New York University School of Law. 
particular subtopic within the trusts and estates field; that is, the scholarship could be critical in the sense that it is necessary or key to understanding a field.

None of these meanings is what we have in mind when we talk about a "critical" research agenda for trusts and estates. For us, critical scholarship uses an "outsider" perspective as a lens to examine the substance and structure of the law. This means more than just making the obligatory passing reference to race, class, gender, or sexual orientation in a law review article. It means examining why the law has developed the way it has and considering what impact the law has on historically disempowered groups such as people of color; women of all colors; lesbian, gay, bisexual, and transgendered individuals; low-income and poor individuals; the disabled; and nontraditional families.

In the allied area of taxation, a small but steady stream of scholarship has emerged over the past two decades. Taken together, this work constitutes the incipient body critical tax scholarship. Both of us self-identify as members of this "movement." We contend that scholarship in the area of the law of wills, trusts, and estates could benefit from similar consideration of the structure and operation of the laws of intestacy, spousal rights, child protection, will formalities, will contests, and will construction; the creation, operation and construction of trusts; fiduciary administration; creditors' rights; asset protection; nonprobate transfers; planning for incapacity and death; and wealth transfer taxation. In each of these areas, it is important to interrogate how and why the law operates to privilege certain kind of people, property, families and transfers.

One might naturally ask why being critical is important in these two "money" areas of the law. It is important because "the suppression of economic personality is intricately connected to the denial of political personality and citizenship. In fact, economic discrimination may be viewed as a key manifestation of political marginalization and social subordination." "In other words, understanding (1) how "money law" operates to benefit certain groups and (2) who those groups are helps to reveal structural barriers to economic flourishing and to expose inequality. Inequality in the economic realm often tracks social and political inequality as well.

This essay provides samples of scholarship that fall loosely in the category of what we call "critical" trusts and estates scholarship. Not all of the authors teach primarily in the trusts and estates area, or even in law schools at all. We do not include here the "best" scholarship, but rather a sample of what we found interesting. The work for all of us is to discover

${ }^{1}$ Adrienne D. Davis, The Private Law of Race and Sex: An Antebellum Perspective 51 STAN. L. REV. 221, 283 (1999). 
and write more of it. To that end, we point out in each of the areas covered in this essay several topics left uncovered and questions that remain to be answered in the hope that others will take up the challenge of adding to this burgeoning literature.

\section{RACE}

Race is central to the story of American property law. Native Americans lived on land later claimed by colonists and settlers in the name of European monarchs. ${ }^{2}$ Through a series of sales ${ }^{3}$ and then treaties ${ }^{4}--$ many of which came to be criticized as greatly disadvantageous to the Native Americans ${ }^{5}$-- European governments took title to land in the area now known as the eastern United States. Settlers received land grants from the crown and then established homes, businesses and agrarian operations, ${ }^{6}$ many of which benefitted from the labor of enslaved Native Americans and then enslaved Africans. ${ }^{7}$ The laws of some colonies codified the status of slaves as property, not persons, beginning as early as 1669. ${ }^{8}$ Slavery developed into a widespread, brutal and exploitative

${ }^{2}$ See, e.g., Howard ZinN, A PeOple's History of the United States 12-16 (1980) (describing pattern of violent capitalistic interactions between Indians and English settlers); William CRONOn, Changes in the LAND: Indians, Colonists, and The ECOLOGY OF NEW ENGLAND (2011) (colonists' changes to land and environment).

3 The most famous of these is perhaps the sale of Manhattan for an alleged twenty-four dollars. See Daniel J. Boorstin, The Americans: The National Experience 259 (1965) ("In 1626, Peter Minuet, in charge of the Dutch settlement on Manhattan Island, paid the Indians sixty gulden for that twenty-thousand acre tract of woodland.")

4 See, e.g., John R. Wunder, "Merciless Indian Savages" and the Declaration of Independence: Native Americans Translate the Ecunnaunuxulgee Document, 25 AM. INDIAN L. REV. 65, 72 ("Between 1777 and 1785, the states of South Carolina, Georgia, North Carolina, and Virginia forced the Cherokees to cede nearly 10,000 acres.").

${ }^{5}$ Otoe \& Missouria Tribe of Indians v. United States, 131 F. Supp. 265, 276-277 (Ct. Cl.) cert. denied, 350 U.S. 848 (1955) (noting that legislative history of Indian Claims Commission Act reflected Congress desire to create remedy in cases "where the Government's dealings with Indians concerning that same property right were less than fair and honorable," inter alia) .

${ }^{6}$ See David A. Thomas, Why the Public Plundering of Private Property is Still a Very Bad Idea, 41 REAL Prop. PROB. \& TR. J. 25, 51 (2006) (in seventeenth century Virginia, "by several devices the vast lands of tidewater Virginia began to shift into private ownership. Farmers completing their tenancies might be in position to buy land outright. Settlers could receive land for their work, and if they properly exploited their first grant, they could receive a second grant of equal size without further investment. Likewise, investors received grants in recognition of their stock, with further grants to follow if the first were profitably developed.").

${ }^{7}$ Laurence Armand French, Native American Reparations: Five Hundred Years and Counting, in When SORRY ISN'T ENOUgh: THE CONTROVERSY OVER APOlOGIES AND REPARATIONS FOR HUMAN INJUSTICE 241, 242 (Roy L. Brooks ed., 1999) (Indian slavery was "not unusual" in certain colonies)

${ }^{8}$ See Paul Finkelman, Slavery in the United States: Persons or Property? in THE LEGAL UNDERSTANDING OF SLAVERY FROM HISTORICAL TO THE CONTEMPORARY (Jean Allain 
institution in the colonies and then the United States. ${ }^{9}$ The institution denied slaves basic human dignities and treated slaves as legal objects, not legal subjects. ${ }^{10}$

The obvious intersections of race, property and testation have been rich inspiration for the work of historians and legal scholars alike. ${ }^{11}$ Stephen Duane Davis II and Alfred L. Brophy provide an example of empirical research in their study of 110 wills probated in Greene County, Alabama from 1831 to 1835 and 1841 to $1845 .{ }^{12}$ The testators they studied were primarily wealthy men who left their property to family members, often through sophisticated trusts. Davis and Brophy look in particular at testators who attempted testamentary manumission of their slaves and the legal constraints in Alabama against doing so. Davis and Brophy are careful to identify the limitations of their research, listing the both the qualitative questions that their research did not answer and inviting further comparative empirical study of wills probated in other Alabama counties.

Adrienne D. Davis does a close reading of several probate cases in her exploration, The Private Law of Race and Sex: An Antebellum Perspective. $^{13}$ In this article, Professor Davis studies a series of judicial decisions involving testamentary transfers by men, mostly white, to women who were former slaves and with whom the testator had a sexual relationship. ${ }^{14}$ Many of the women in the cases shared children with the testator. Professor Davis is interested in sorting through "those sexual or

ed. 2012), 105-134, 113-114 (describing Virginia law of 1669 providing for immunity for slave owners who caused death when punishing own slaves).

9 See, e.g., David Brion Davis, Inhuman Bondage: The Rise ANd FAll of Slavery IN THE NEW WORLD (2006).

${ }^{10}$ See, e.g., M. Eugene Sirmans, The Legal Status of the Slave in South Carolina, 16701740, 28 J. S. HIST. 462 (1962) (slaves treated as legal chattel).

11 See, e.g., We ARE Your Sisters: Black WOMEN IN THE NineteEnth Century (Dorothy Sterling ed. 1984) (identifying 100 wills in which white men transferred property by will to black women); CAROLE Shammas, Marylynn SLAmON \& Michel DAHLIn, INHERITANCE IN AMERICA FROM COLONIAL TIMES UNTIL THE PRESENT (1987); Hendrik A. HaRtog, SOMEDAY All This Will Be Yours: A History of INHERITANCE AND OLD AGE (2012).

12 The Davis-Brophy study is modeled after a similar study conducted in San Bernadino County, California by Stanford Law Professor Lawrence M. Friedman and his co-authors. See Lawrence M. Friedman, et al., The Inheritance Process in San Bernardino, California, 1964: A Research Note, 43 Hous. L. REV. 1445 (2007).

13 Adrienne D. Davis, The Private Law of Race and Sex: An Antebellum Perspective 51 STAN. L. REV. 221 (1999).

${ }^{14}$ Professor Davis explains her rejection of terms like "mistress," "lover," or "partner," among others, to describe these relationships: "Many phrases which appear descriptive, or which I might use as terms of art, carry too much social baggage to be helpful....[M]ost of these terms cannot account for the complexity of nineteenth century male sexual power combined with race and status differences." Id. at n.17. 
biological relationships that yield legal obligations and entitlements and those that do not," 15 and the way that race factors into the determination. She discusses the case of Jolliffe v. Fanning \& Phillips, ${ }^{16}$ in which the nominated executors under one will sought to set aside a subsequentlyexecuted will in which the white testator freed his concubine and their shared children and directed the liquidation of his estate for their benefit. The concubine and children were located in Ohio, but the testator's will was probated in South Carolina, his presumed domicile. South Carolina law prohibited testamentary manumission of slaves. The court upheld the disposition in favor of the concubine and the shared children on the grounds that they had been freed during the testator's lifetime (and thus the attempted testamentary manumission was invalid, but the validity of the will itself was undisturbed). While noting the positive outcome for the testator's intended beneficiaries, Professor Davis examines a tension in the court's rhetoric between deference to testamentary freedom and overt disapproval of the testator's private sexual choices. ${ }^{17}$ The article explains how the law confronted these conflicts between "the ideologies of property and race," along with other conflicting ideologies of "race, sexuality and gender roles." 18

Another example of an historical exploration of testation and race is Kevin Noble Maillard's The Color of Testamentary Freedom. ${ }^{19}$ In that article, Professor Maillard raises questions about the role of race in courts' willingness to uphold donative transfers. He uses as his focal point two will contests involving the family of Paul Remley of Charleston, South Carolina. The elder Mr. Remley left property to his wife and appointed his son Paul Durbin Remley as administrator. A collateral relative stepped forward to assert that Mr. Remley's widow was a slave, and as such, the bequest to her was invalid and Paul Durbin Remley was ineligible to serve as administrator. ${ }^{20}$ This claim was defeated upon community testimony that the widow was treated by her church and other neighbors as white. ${ }^{21}$ Mr. Remley's will was upheld only after a judicial showing of the whiteness of his wife, and thus, their children.

When Mr. Remley's son, Paul Durbin Remley, died three years after his father, he left his estate in trust for the benefit a slave, with whom

\footnotetext{
${ }^{15} I d$. at 225.

${ }^{16} 44$ S.C.L. (10 Rich.) 186 (1856).

${ }^{17}$ Davis, supra note 13, at 256 (the court's opinion "gave legal force to Willis' [the testator's] impulse to provide for his black family, even as it strongly condemned the conduct that motivated him").

${ }^{18} I d$. at 286.

${ }^{19}$ Kevin Noble Maillard, The Color of Testamentary Freedom, 62 SMU L. REV. 1783 (2009).

${ }^{20} I d$. at 1797-1798.

${ }^{21}$ Id.
} 
he fathered to children, and their mixed-race children. Remley's siblings, whose white racial identity had been challenged in the earlier will contest, then stepped forward to contest the validity of the younger Remley's bequest for the benefit of his slave family. At the time, South Carolina law prohibited bequests to slaves. ${ }^{22}$ The case was settled after the enactment of the Thirteenth Amendment outlawing slavery, and the amount of the testamentary trust was sharply reduced. ${ }^{23}$ Professor Maillard argues that this case illustrates that the court "and collateral heirs ignore testamentary language to reformulate a will to more closely conform to state-mandated schemes of distribution. ${ }^{24}$ In other words, race had everything to do with how both generation of Remley family wills were interpreted.

The historical experience of slavery and the law of succession give rise to a contemporary problem in modern-day South Carolina, as explored by Professor Faith Rivers in her work on African-American "heirs' property" in the Lowcountry of South Carolina. Her article Inequity in Equity: The Tragedy of Tenancy in Common for Heirs' Property Owners Facing Partition in Equity ${ }^{25}$ explains South Carolina's experience of post-Civil War land distribution. Although the South Carolina Land Commission was poorly managed and ultimately benefitted more whites than blacks, these sales, combined with private transactions and federal sales, enabled 16,000 African-Americans to acquire 50,000 acres, mostly in South Carolina's Lowcountry. ${ }^{26}$ As Professor Rivers explains, however, a variety of factors -- including low numbers of African-American lawyers, general distrust of private attorneys, and high costs -- kept many Lowcountry landowners from turning to lawyers for advice on property-related issues, such as succession. ${ }^{27}$ Without a will, the law of intestacy governs the disposition of a decedent's property, resulting in fractionalization of property interests when, for example, a landowner who is survived by five children and no spouse, each child will take a one-fifth interest in the property as tenants in common. Practically speaking, over generations, property ownership becomes increasingly fractionalized. A single parcel of property may be owned by hundreds of family members, some of whom are only distantly related, and may not know each other at all. ${ }^{28}$

\footnotetext{
${ }^{22}$ Id. at n.127 (Act to Prevent the Emancipation of Slaves, and for Other Purposes (1841) (citations omitted).

${ }^{23}$ Maillard, supra note 19, at 1809.

${ }^{24}$ Maillard, supra note 19, at 1804.

${ }^{25}$ Faith Rivers, Inequity in Equity: The Tragedy of Tenancy in Common for Heirs' Property Owners Facing Partition in Equity, 17 TEMP. POL. \& CIV. RTS. L. ReV. 1 (20072008).

${ }^{26} I d$. at 25 .

${ }^{27}$ Id. at $26-28$

28 “"T] he entire class of heirs' property owners -- ranging from small, nuclear families of siblings who inherit property from the original purchasers, to hundreds of cousins and
} 
Separate from property management concerns, tenancy in common gives rise to the possibility of a forced partition by sale. Legally speaking, if the tenants in common cannot agree on how the property should be used, the appropriate legal remedy is partition. Depending on the jurisdiction, the partition may be in kind, i.e., division of the property into individually-owned interests representing each owner's fractional interest in the whole ${ }^{29}$ or by sale and division of the proceeds. Using cases from the nineteenth century, Professor Rivers reveals that South Carolina's partition doctrine has roots in the system of slavery, as partition (by sale) was the remedy developed by courts in cases where human beings regarded by law as property, or slaves, comprised part of a decedent's estate. ${ }^{30}$ Because South Carolina's doctrine is partition by sale, then all it takes in contemporary South Carolina Lowcountry is one disgruntled coowner -- or perhaps one approached by an unscrupulous developer -- to force other owners of to sell. Professor Rivers is concerned that owners of "heirs' property," as this fractionated Lowcountry property is called, could be subject to pressures from developers to sell their land, thus suffering the fate of Hilton Head Island, South Carolina, which used to have a population that was $90 \%$ black and was less than $15 \%$ black in $1975 .{ }^{31}$

In considering how to stem the possible erosion of black-owned property, Professor Rivers notes with approval other jurisdictions' experience with partition in-kind and rules that would grant a right of first refusal of sorts to co-owners, ${ }^{32}$ as well as other states' more protective procedural rules for partition. ${ }^{33}$

Professor Rivers' work builds on an earlier article, Through a Colored Looking Glass: A View of Judicial Partition, Family Land Loss, and Rule Setting, ${ }^{34}$ by Phyllis Craig-Taylor. Professor Craig-Taylor provides a thorough history and overview of the development of the American law of partition and offers a biting critique of the "inconsistencies and potential unfairness" produced in most cases involving a sale of property after judicial partition. ${ }^{35}$ Professor CraigTaylor argues that African-Americans have been disproportionately

relatives who inherited property over the course of 150 years -- are left to "work out among themselves' how property will be managed." Id. at 51 (citation omitted).

${ }^{29}$ BLACK'S LAW DiCTIONARY ( $9^{\text {th }}$ ed. 2009), partition.

${ }^{30}$ Rivers, supra note $25,39-40$.

${ }^{31} I d$. at 30.

${ }^{32} I d$. at $69-71$.

${ }^{33}$ Id. at $74-75$.

${ }^{34}$ Phyllis Craig-Taylor, Through a Colored Looking Glass: A View of Judicial Partition, Family Land Loss, and Rule Setting, 78 Wash. U. L.Q. 737 (2000).

${ }^{35}$ Id. at 759 . 
affected by the judicial partition cases, because are more likely than whites to inherit property via intestacy, and thus own fractionated interests in land. $^{36}$ She also claims that the history of African-Americans in this country causes them to value land ownership more than other types of asset ownership, ${ }^{37}$ and as such, land ownership is a sort of cultural patrimony being destroyed by judicial partition. Professor Craig-Smith proposes modification of partition laws to make it more difficult to force the sale of property owned as tenants in common, as well as a generous "redemption period," in which non-selling family members would have the right to buy the property from those wishing to force the sale. ${ }^{38}$

Palma Joy Strand provides a contemporary perspective on race and inheritance in her article Inheriting Inequality: Weath, Race, and the Laws of Succession. ${ }^{39}$ Strand is concerned with the ways that inheritance perpetuates wealth disparities between black and white households. She presents data about overallwealth inequality in the United States, and examines wealth disparities among whites and among blacks. She finds a more significant intra-racial disparity among blacks than among whites. ${ }^{40}$ Strand observes that comparatively fewer blacks than whites receive inheritances. ${ }^{41}$ She claims that racial wealth disparities are "today's version of yesterday's segregation and the slavery of the day before," 42 or, in other words, the present-day consequences of past de facto and de jure discrimination. To remedy racial disparities, Strand suggests treating gifts, bequests, devises and inheritances as income. ${ }^{43}$ She also notes problems that arise with "heirs' property," as Faith Rivers does in her study of South Carolina. ${ }^{44}$ Strand explains how the failure to probate an estate and clear title to what may be the family's largest asset -- the home - wealth can erode in a matter of one or two generations. Strand proposes reforming the intestacy statute to eliminate fractionated ownership of small estates consisting of a family home and to simplify transfer of title at death. $^{45}$ This portion of Strand's investigation might provide the fruitful

\footnotetext{
36 Id. at 737 ("African Americans tend not to engage in estate planning; thus disproportionately, their real property passes under the laws of intestacy, making $t$ more likely for property to be owned under the co-ownership forms that are subject to partition.") (citations omitted).

${ }^{37}$ Id. at 737 ("cultural and sociological studies suggest that African Americans value land ownership beyond the market value that the relevant land commands").

${ }^{38}$ Craig-Taylor, supra note 34 , at 780-785.

${ }^{39}$ Palma Joy Strand, Inheriting Inequality: Wealth, Race, and the Laws of Succession, 89 OR. L. REV. 453 (2010-2011).

${ }^{40} \mathrm{Id}$. at 462-463.

${ }^{41}$ Id. at 467.

${ }^{42} I d$. at 377 (emphasis in the original).

${ }^{43}$ Strand, supra note 39 , at 485.

${ }^{44}$ See supra notes _ to

${ }^{45}$ Strand, supra note 39 , at 501.
} 
basis for additional scholarship, in an effort to create sensible rules that are easy to administer and ones that do justice.

Most of the scholarship involving race and testation tends to be historical. The relative availability of formal court records make wills particularly ripe for empirical and qualitative studies. To be sure, much work remains to be done to reveal how testators in different parts of the country historically have disposed of their property and how past sociolegal and political events caused patterns of testation to change. Formal legal documents such as wills and trusts can reveal a wealth of information about the racial attitudes and hierarchies of previous generations. Existing scholarship focuses on slavery in the American South. Scholars might choose to explore historic wills in the Midwest or West, areas with different historic experiences of racial inclusion and exclusion. Stories of patterns of testation and property ownership among people of Chinese, Japanese and Mexican ancestry, among others, are waiting to be told.

Contemporary wills practice, particularly as it relates to race, is another wide-open scholarly ground waiting to be occupied. Cross-racial studies of wealth accumulation and transmission could effectively move scholarship in this area out of a black-white binary to reveal more nuanced understandings of different attitudes and behaviors concerning wealth and inheritance. There appears to be no substantial legal scholarship addressing contemporary Asian-American, Latino or Native American testation.

Robust critical scholarship in the area of wills, trusts and estates might fruitfully begin to look behind the study of wills themselves to intersections of race with other areas. For example, consider patterns and practices of planning for incapacity and death. Are some racial groups more likely to execute living wills and health care proxies? If so, why is this the case? What cultural factors might influence those practices? On the subject of trusts, scholars might look at the extent to which charitable giving, particularly in the form of trusts, has been used to replicate or disrupt racial hierarchies. A worthwhile scholarly project might be mapping judicial responses to them in different historical and contemporary contexts. A variety of "Indian funds" are held by the federal government, ${ }^{46}$ and academic inquiry of the operation of these trusts could fruitfully illuminate issues of self-determination and ownership that are of great importance to Native Americans. There is so much more to discover about the intersections of race with wills, trusts and estates.

${ }^{46}$ See, e.g., American Indian Trust Fund Management Reform Act of 1994, Pub. L. No. 103-412, 108 Stat. 4293 (1994) (codified as amended at 25 U.S.C.S. $\S \S 4001-61(2012)$ ). 


\section{GENDER}

Scholarship in the area of wills, trusts and estates that is concerned with gender tends to address one of three questions: (1) How are women's wills different than men's wills? (2) How does the probate process or the substance of wills that have been probated implicate questions of gender? (3) How does gender inform attitudes toward estate planning?

\section{A. Women's and Men's Wills}

An excellent example of scholarship in this first category is Kristine Knapulund's article The Evolution of Women's Rights in Inheritance. ${ }^{47}$ Knaplund made a detailed study of 246 probate files from Los Angeles County, California in $1893 .{ }^{48}$ She locates her work in the larger historical context of the 1861 California Married Womens' Property Act which allowed women to manage and control their separate property and subsequent legislative changes enacted in 1872 that gave women full control over their separate property. ${ }^{49}$ Knaplund found that a substantial number of women executed wills $(29 \%$ of testate decedents were women $)^{50}$, that women were more likely than men to leave their property to children or family members than to a surviving spouse, ${ }^{51}$ and that property left to women typically passed outright, and not in trust. ${ }^{52}$ Professor Knaplund's archive-based methodology is consistent with the same empirical tradition that informed earlier studies by Steven Duane Davis II and Alfred L. Brophy, ${ }^{53}$ among others. ${ }^{54}$ Knaplund's work enhances understanding of "women as an economic force in California" in

\footnotetext{
${ }^{47}$ Kristine S. Knaplund, The Evolution of Women's Rights in Inheritance, 19 HaSTINGS WOMEN'S L.J. 39 (2008).

${ }^{48} I d$. at 5-6.

${ }^{49} I d$.

${ }^{50} I d$. at Figure 6.

${ }^{51} \mathrm{Id}$. at 39

${ }^{52}$ Knaplund, supra note 47, at 39.

${ }^{53}$ See supra notes _ and accompanying text.

${ }^{54}$ Knaplund cites to seven other empirical studies of wills with "comparable methodology" to the one deployed in her project: Steuart Henderson Britt, The Significance of the Last Will and Testament, 8 J. OF Soc. PSYCHOL. 247 (1937); Allison Dunham, The Method, Process and Frequency of Wealth Transmission at Death, $30 \mathrm{U}$. CHI. L. REV. 241 (1962-63); Lawrence M. Friedman, Patterns of Testation in the 19 $9^{\text {th }}$ Century: A Study of Essex County (New Jersey) Wills, 8 AM. J. OF LEGL HIST. 24 (1964); Contemporary Studies Project, A Comparison of Iowans' Dispositive Preferences with Selected Provisions of the Iowa and Uniform Probate Codes, 63 IowA L. REV. 1941 (1977-78); Olin L. Browder, Jr., Recent Patterns of Testate Succession in the United States and England, 67 MicH. L. REV. 1303 (1968-69); Edward J. Ward and J.J.

Beuscher, The Inheritance Process in Wisconsin, 1950 WIS. L. REV. 393 (1950). See also Davis and Brophy, supra note
} 
the nineteenth century and draws attention to the ways that women's wills tended to be different than men's wills.

Daphna Hacker provides an overview of extant empirical scholarship on wills The Gendered Dimensions of Inheritance: Empirical Food for Legal Thought. ${ }^{55}$ Professor Hacker provides a narrative review of 23 studies that bear in some way on issues of gender and inheritance. In Western societies and in Israel she finds, women "enjoy privilege, power, and control" in the realm of testation, as women execute wills at approximately the same rate, or even at higher rates, than men do. ${ }^{56}$ Professor Hacker reports that testate men tend to leave their property entirely to the surviving spouse, whereas women tend to have a broader range of heirs, including children. ${ }^{57}$

Alyssa DiRusso considers the extent to which gender influences the language that male and female testators use in He Says, She Asks: Gender, Language, and the Law of Precatory Words in Wills. ${ }^{58}$ Professor DiRusso surveyed 324 individuals about their preferred wording for certain will provisions. She found that "women were more likey to use precatory language than men and people who intended to grant discretion to their executors were more likely to use precatory language than those who intended to bind their executors." 59 Thus, she concludes that courts "must give greater credence to ascertaining the intended meaning of the language the testator chose," 60 instead of employing bright-line tests that would treat certain words as always binding and others as always precatory. Professor DiRusso acknowledges that her findings might be complicated by the involvement of attorneys in the drafting process, but notes that a large percentage of all wills are drafted without attorneys. ${ }^{61}$ She does not specify how the availability of computerized will programs or even legal forms might complicate the analysis, but her basic thesis is clear: for reasons of biology or culture, men and women might use different words, and the search for testamentary intent should be informed by a gender-sensitive understanding of how men and women may communicate differently.

\footnotetext{
${ }^{55}$ Daphna Hacker, The Gendered Dimensions of Inheritance: Empirical Food for Legal Thought, 7 J. EMPIRICAL LEGAL STUD. 322 (2010).

${ }^{56}$ Id. at $350,331-334$

${ }^{57}$ Id. at 335 .

${ }^{58}$ Alyssa A. DiRusso, He Says, She Asks: Gender, Language, and the Law of Precatory Words in Wills, 22 WIS. WoMEN's L.J. 1 (2007).

${ }^{59}$ Id. at 46.

${ }^{60} \mathrm{Id}$. at 49.

${ }^{61} \mathrm{Id}$. at 47.
} 


\section{B. Probate Courts, Probated Wills, Women and Men}

Donative intent is not the only principle which guides a court's interpretation of a will. As Professor Melanie Leslie has observed, many courts use malleable doctrines such as undue influence in order to impose "a duty to provide for those whom the court views has having a superior moral claim to the testator's assets, usually a financially dependent spouse or persons related by blood to the testator. ${ }^{, 62}$ In other words, where a testator deviates too far from majoritarian norms for the disposition of his or her property, a court may set aside those dispositions. In a student note published in 1997, Brian Alan Ross explores how the doctrine of undue influence is permeated with gender stereotypes in Undue Influence and Gender Inequity. ${ }^{63} \mathrm{He}$ examines several cases in which a contestant alleges the existence of a "meretricious relationship" that caused the testator's free will to be so overcome that the testator made a disposition that he or she would not have made otherwise. ${ }^{64}$ Ross closely reads a series of cases and concludes that "courts often apply the undue influence doctrine in a way that strongly pressures women to conform to traditional gender roles, by mischaracterizing them and in some instances stripping them of their testamentary privileges if they challenge various ideals of femininity, monogamy and marriage." ${ }^{.55}$ Decisions involving older women with younger men portray the older women as "worthless and submissive," having personal preferences that easily overcome, whereas young women with older men are portrayed as "the cunning temptress.",66 Scholars have paid increasing attention in recent years to the doctrine of undue influence, exploring how dominant cultural norms inform how judges and juries evaluate claims of undue influence. ${ }^{67}$ Gender and sexuality have informed several of these analyses, but much there is continued room for additional scholarship in this area, along with allied investigations into claims of fraud in the inducement to execute a will and claims of tortuous interference.

\footnotetext{
${ }^{62}$ Melanie B. Leslie, The Myth of Testamentary Freedom, 38 ARIZ. L. REV. 235 (1996).

${ }^{63}$ Brian Alan Ross, Undue Influence and Gender Inequity, 19 WoMEN's RTS. L. REP. 97 (1997).

${ }^{64}$ See Restatement (Third) of Property: Wills and Other Donative Transfers $\S 8.3(\mathrm{~b}) \mathrm{cmt}$. e (2003) ("A donative transfer is procured by undue influence if the influence exerted over the donor overcame the donor's free will and caused the donor to make a donative transfer that the donor would not otherwise have made.").

${ }^{65} \mathrm{Id}$. at 100 .

${ }^{66} \mathrm{Id}$. at 115.

${ }^{67}$ See, e.g., Carla Spivack, Why the Testmentary Doctrine of Undue Influence Should be Abolished, 58 U. KAN. L. REV. 245 (2010); E Gary Spiko, Gone but not Conforming: Protecting the Abhorrent Testator from Majoritarian Cutlural Norms Through MinorityCulture Arbitration, 49 CASE W. RES. L. REV. 275 (1999); Ray Madoff, Unmasking Undue Influence, 81 MinN. L. REV. 571 (1997). See also Jeffrey G. Sherman, Undue Influence and the Homosexual Testator, 42 U PITT. L. REV. 225 (1981).
} 
Not precisely under the heading of "probate courts treating men and women differently," but relating the broad questions of inheritance is Professor Carla Spivack's work considers whether some heirs should be deemed to be "unworthy" to inherit. Professor Spivack takes up that question in the context of battering spouses. ${ }^{68}$ She proposes a "complete ban" on inheritance of both probate and non-probate property by abusing spouses. $^{69}$ Professor Spivack's scholarship creatively considers how a comprehensive campaign against domestic violence implicates the substantive law of wills and trusts. In that sense, it is a model of scholarship that explores how an issue of traditional concern for feminist scholars -- in this case, domestic violence -- might have implications for a seemingly unrelated area of inheritance and property.

Daphna Hacker's review of empirical studies of inheritance reports on the discrimination that female heirs experience in Tanzania ${ }^{70}$ and South Asia, ${ }^{71}$ for example. In most Westerns societies, in contrast, most parents "treat their offspring equally regardless of sex," she reports, but certain property like jewelry typically passes to daughters and farms and businesses typically pass to sons. ${ }^{72}$ It appears that in Western and Israeli societies, women are more likely or equally likely to contest a will, but that wills benefitting women are more likely to be contested than those benefitting men. ${ }^{73}$

Mary Louise Fellows looks at the substance of testamentary trusts in Wills and Trusts: "The Kingdom of the Fathers."74 Professor Fellows exposes the qualified terminable interest property (or "QTIP") trust as evidence of "the patriarchy's subversion of women's property rights," 75 in that (typically male) testators could qualify for a $100 \%$ estate tax marital deduction even though they left their (female) surviving spouses only an income interest in a trust over which the surviving spouse had no power of appointment. Professor Wendy Gerzog expanded this critique in her article The Marital Deduction QTIP Provisions: Illogical and Degrading

\footnotetext{
${ }^{68}$ Carla Spivack, Let's Get Serious: Spousal Abuse Should Bar Inheritance, 90 Or. L. REV. 247 (2011)

${ }^{69}$ Id. at $248-249$.

${ }^{70}$ Hacker, supra note 55, at 336-337.

${ }^{71} I d$. at 337.

${ }^{72}$ Id. at $337-338$.

${ }^{73} \mathrm{Id}$. at 344 .

${ }^{74}$ Mary Louise Fellows, Wills and Trusts: The Kingdom of the Fathers, 10 LAW \& INEQ. 137 (1991).

${ }^{75} \mathrm{Id}$. at 158 .
} 
to Women. ${ }^{76}$ Professor Gerzog sees the QTIP as evidence of "clear gender bias and stereotyping,"

C. Estate Planning

In “Where There's a Will, There's a Woman”: Exploring the Gendered Nature of Will Making, ${ }^{78}$ Ezra Hasson considers gender issues in the estate planning context. He conducted interviews with 26 estate planners in the East Midlands area of England; the practitioners served clients from diverse social classes. Hasson's interviews revealed that women were more likely than men to initiate estate planning process ${ }^{79}$ and that women tend to "dominate practitioner-cleint meetings. ${ }^{80}$ Hasson hypothesizes that women's seeming greater involvement in the process is extension of their mothering role (i.e., involving caring for and managing the fiscal health of the family, as well as securing the children's future), as well as self-interested, as women tend to outlive their male partners. ${ }^{81}$ Hasson's conclusions are the practitioners might effectively target their services toward women ${ }^{82}$ and that the government needs to do more to increase public awareness in general of the importance of having a will. ${ }^{83}$

D. Additional Avenues of Inquiry

While it may be true that the law of inheritance is, as Daphna Hacker claims, "one of the most impressive achievements of liberal feminism," 84 there is much scholars do not know about how gender is at play in the operation of the law of wills, trusts, and estates. Apart from the QTIP trust, feminist scholars have not devoted substantial scholarly attention to the operation of trusts. In what ways might trusts operate to perpetuate women's financial dependence on men? To what extent do trusts limit women's control over money that arguably belongs in part to them, if accumulated during a long-term marriage?

A scholar interested in different attitudes and behaviors of men and women might consider gender differences in attitudes about investment,

\footnotetext{
${ }^{76}$ Wendy C. Gerzog, The Marital Deduction QTIP Provisions: Illogical and Degrading to Women, 5 UCLA WOMEN's L.J. 301 (1995).

${ }^{77} \mathrm{Id}$. at 322 .

${ }^{78}$ Ezra Hasson, "Where There's a Will, There's a Woman": Exploring the Gendered Nature of Will Making, 21 Feminist LEGAL STUD. 21 (2013).

${ }^{79} \mathrm{Id}$. at 25 .

${ }^{80} \mathrm{Id}$.

${ }^{81}$ Id. at 33-34.

${ }^{82}$ Id. at 35 .

${ }^{83}$ Hasson, supra note 78 , at 35 .

${ }^{84}$ Hacker, supra note 55, at 350.
} 
and how different tolerances for risk may bear on the fiduciary standard (first the "Prudent Man" rule ${ }^{85}$ and now the "Prudent Investor" rule ${ }^{86}$ ) to which fiduciaries are held. Also, are there any differences in how men and women use the money they inherit? ${ }^{87}$ We know very little about what people do with assets they have acquired from previous generations.

The practical impact of legal reform on how men and women organize their finances is another field of investigation. Four areas come to mind. First, self-settled asset protection trusts are twentieth century innovation about which little is known. Who creates these trusts and have they changed the divorce landscape in any way? Second, elective community property regimes have been enacted in two jurisdictions, Alaska $^{88}$ and Tennessee. ${ }^{89}$ How couples have chosen to avail themselves of these arrangements, and what are their motivations for doing so? Third, the enactment of estate tax portability has limited the financial incentives to equalize a husband's and wife's estate during their lifetimes. ${ }^{90}$ How has the structure of the tax system changed the way that husbands and wives organize their finances? Finally, what do we know about gendered dimensions of perpetual trusts? Who creates them and for what purposes? Are perpetual trusts the ultimate manifestation of patriarchal control, or can they be read in a more feminist light?

The legal profession itself should not escape critical study. To what extent have women advanced to leadership positions in the Trusts \& Estates bar at a rate that is faster, slower or comparable to other specialty areas? How has the field of Trusts \& Estates been more or less accommodating to female attorneys, and what changes might one expect to see? In recent memory, the reporters for Uniform Statutory Rule Against Perpetuities, the Uniform Simultaneous Death Act, and the Uniform Testamentary Additions to Trusts Act, the Restatement (Third) of Property: Wills and Other Donative Transfers. The reporter Uniform Prudent Investor Act (1994) and most Uniform Law Commissioners have been men. How might the lack of gender diversity impact the "top down"

${ }^{85}$ See, e.g., Max M. Schanzenbach \& Robert H. Sitkoff, Did Reform of Prudent Trust Investment Laws Change Trust Portfolio Allocation?, 50 J.L. \& ECON 681 (2007).

${ }^{86}$ Unif. Prudent Investor Act (1994)

${ }^{87}$ Daphna Hacker notes only one study that addresses this issue. See Hacker, supra note 55, at 345 (referring to JANET FINCH ET AL., WILLS, INHERITANCE AND FAMILIES (1996).

${ }^{88}$ See Alaska Stat. $\S 34.77 .100$ to .160 (2013).

${ }^{89}$ See Tenn. Code Ann. § 35-17-101 to -108 (2013).

${ }^{90} \mathrm{See}$ [insert cite]. 
reforms?" And of the important "bottom up" reforms coming from practitioners, ${ }^{92}$ what has been women's involvement? Anectodal evidence suggests that women's participation has been almost non-existent. What does that say about women's role in the Trusts \& Estates bar? The legal profession itself? Perhaps we should not be too quick to praise the "achievements of liberal feminism" in the area of inheritance law.

\section{SEXUAL ORIENTATION}

Prior to the advent of same-sex marriage in Massachusetts, ${ }^{94}$ there was a burgeoning literature on the heteronormativity of state intestacy laws. In The Expressive Function of Succession Law and the Merits of Non-Marital Inclusion, Professor Gary Spitko examined article II of the Uniform Probate Code (UPC), which addresses intestate succession, and identified seven different values that underpin that portion of the UPC. ${ }^{95}$ As Professor Spitko identified these values, he analyzed whether the refusal to recognize committed same-sex relationships under article II is consistent with the values underpinning it. ${ }^{96}$ Ultimately, Professor Spitko concluded that it is inconsistent with the values underpinning article II to exclude committed same-sex couples from the default protections embodied in intestacy laws. ${ }^{97}$ Professor Spitko suggested that the drafters of the UPC could take account of committed same-sex relationships in article II through a combination of reliance upon a domestic partner registration system and a "multi-factor approach that limits judicial discretion through objective requirements and clearly delineated factors for qualification or a combination of these two systems." 98

Against this background, Professor Spitko considered the expressive function of succession laws, as "intestacy law not only reflects society's familial norms but also helps to shape and maintain them." 99 Professor Spitko considered ways in which the drafters of the UPC could take account of committed same-sex relationships while still threading

${ }^{91}$ See Max M. Schanzenbach \& Robert Sitkoff, The Prudent Investor Rule and Trust Asset Allocation: An Emprical Analysis, 35 ACTEC 314, 314, 318 (2010).

${ }^{92} I d$.

${ }^{93}$ Supra note 84.

${ }^{94}$ Opinions of the Justices to the Senate, 802 N.E.2d 565 (Mass. 2004); Goodridge v. Dep't of Pub. Health, 798 N.E.2d 941 (Mass. 2003).

${ }^{95}$ E. Gary Spitko, The Expressive Function of Succession Law and the Merits of NonMarital Inclusion, 41 ARIZ. L. REV. 1063, 1067-99 (1999).

${ }^{96} I d$.

${ }^{97}$ Id. at 1099.

${ }^{98} \mathrm{Id}$. at 1107.

${ }^{99} \mathrm{Id}$. at 1100 . 
their way between the opposing sides in the ongoing culture war over the expressive function of the law in affirming or stigmatizing same-sex relationships. ${ }^{100}$ Though allowing for the possibility that the drafters might wish to stay out of these battles, Professor Spitko concluded that avoiding even an acknowledgment of committed same-sex relationships itself constitutes taking a side, and explained that, whichever side the drafters ultimately take, acknowledging committed same-sex relationships would be a step forward. ${ }^{101}$

Similarly, in Default Rules, Mandatory Rules, and the Movement for Same-Sex Equality, Professor Tom Gallanis argued that the lesbian, gay, bisexual, and transgender (LGBT) rights movement needs to fight to change not only mandatory rules (e.g., prohibitions against same-sex marriage or limiting the categories of individuals who may adopt) but also the often overlooked default rules that discriminate on the basis of sexual orientation. ${ }^{102}$ As an example of a set of default rules that discriminate on the basis of sexual orientation, Professor Gallanis analyzed the impact of laws governing intestate succession, healthcare decision making, and guardianship on members of the LGBT community. ${ }^{103}$ Professor Gallanis advocated the undertaking of empirical research to determine which default rules the LGBT community would generally prefer and considered some of the difficulties that might arise in drafting workable legislation. ${ }^{104}$

In the 1990s and early 2000s, commentators, including Professors Spitko and Gallanis, drafted proposed statutory language extending the coverage of succession laws to unmarried, committed partners. ${ }^{105}$ In the midst of this flurry of reform proposals, Professor Mary Louise Fellows and a group of researchers undertook a small empirical study, published under the title Committed Partners and Inheritance, which began the work of determining which default rules the LGBT community and other committed unmarried couples would prefer. ${ }^{106}$ Professor Fellows and her team compared the results of this small study, which found that a majority would provide a share of the decedent's estate to a surviving same-sex or

\footnotetext{
${ }^{100} \mathrm{Id}$. at $1099-1103$.

${ }^{101} I d$. at $1105-06$.

102 T.P. Gallanis, Default Rules, Mandatory Rules, and the Movement for Same-Sex Equality, 60 OHIO ST. L.J. 1513, 1514-16 (1999).

${ }^{103} I d$. at $1517-22$.

${ }^{104} I d$. at $1524-28$.

${ }^{105}$ T.P. Gallanis, Inheritance Rights for Domestic Partners, 79 TUL. L. REV. 55 (2004); E. Gary Spitko, An Accrual/Multi-Factor Approach to Intestate Inheritance Rights for Unmarried Committed Partners, 81 OR. L. REV. 255 (2002). In his article, Professor Spitko also included a copy of Professor Lawrence Waggoner's proposal as an appendix. Spitko, supra, at

${ }^{106}$ Mary Louise Fellows et al., Committed Partners and Inheritance: An Empirical Study, 16 LAW \& INEQ. 1 (1998).
} 
different-sex partner, with the then extant reforms and reform proposals. 107 They also set forth throughout their paper areas that should be explored in future empirical research. ${ }^{108}$

Unfortunately, as the number of states legally recognizing samesex relationships has grown, it appears that interest in this topic has waned. ${ }^{109}$ This is a pity - and not only because (1) the majority of states still refuse to legally recognize same-sex relationships ${ }^{110}$ and (2) the UPC still does not directly take account of same-sex relationships. ${ }^{111}$ Even were all states to relieve the discrimination identified by Professors Spitko and Gallanis by legally recognizing same-sex relationships and to honor the preferences of those participating in Professor Fellows's study, the laws governing intestate succession would still be ripe for reexamination. Eliminating de jure discrimination against same-sex couples by affording them access to marriage merely adds another group to a privileged circle. It does nothing to eliminate the broader privileges based on marital status and conformance to the "traditional" family norm of a conjugal couple surrounded by children. Thus, as currently drafted, the UPC continues not only to reflect but to further entrench the privileging of marriage, attempting to skew and direct choices regarding family formation rather than leaving it to the affected individuals to choose the family form that best suits them.

It is worth picking up this line of inquiry once again, but not merely to explore how to accommodate committed same-sex relationships in the states that continue to refuse them legal recognition. Instead, the focus should be on exploring how wills, trusts, and estates law might be reformed to break down this privileging and embrace the multiplicity of family forms that exist. In other words, how might the variety of default rules that exist be reformed to embrace diverse family structures, making it both easier and cheaper for these individuals to engage in estate

\footnotetext{
${ }^{107}$ Id. at $89,94-95$.

${ }^{108}$ Id. passim.

109 Aside from the occasional student note on this topic. E.g., Madeleine N. Foltz, Comment, Needlessly Fighting an Uphill Battle: Extensive Estate Planning Complications Faced by Gay and Lesbian Individuals, Including Drastic Resort to Adult Adoption of Same-Sex Partners, Necessitate Revision of Maryland's Intestacy Law to Provide Heir-at-Law Status for Domestic Partners, 40 U. BALT. L. REV. 495 (2011); Charles P. Schwartz, Note, Thy Will Not Be Done: Why States Should Amend Their Probate Codes to Allow an Intestate Share for Unmarried Homosexual Couples, 7 CONN. PUB. INT. L.J. 289 (2008).

110 Statewide Marriage Prohibitions, Human Rights CAMPAign (July 2, 2013), http://www.hrc.org/files/assets/resources/marriage prohibitions 072013.pdf.

${ }^{111}$ UNIF. PROBATE CODE $\S \S 2-101$ to -105 (amended 2010). The UPC only takes account of same-sex relationships indirectly; that is, to the extent that state law permits same-sex couples to enter into legal relationships that confer spousal status upon them.
} 
planning while at the same time insulating them from collateral attack by disgruntled or disagreeable "traditional" family members?

Another interesting line of inquiry might focus on the lawyers who are providing estate planning advice. How does their own point of view influence the type of advice that they provide to LGBT clients and others in nontraditional family relationships? Put differently, do they unconsciously push nontraditional families toward conformance to traditional family norms? As Professor Amy Ronner observes in Homophobia: In the Closet and in the Coffin, it is not only estate planning attorneys that we should worry about but also the judges who hear cases involving decedents' estates. ${ }^{112}$ In that article, Professor Ronner examines the heterosexism displayed by the judges in Vasquez v. Hawthorne. ${ }^{13}$ In Vasquez, the Washington courts considered whether judicial decisions affording some of the property rights associated with marriage to "meretricious" relationships (i.e., where a couple cohabits outside of marriage) should be extended to cover a surviving same-sex partner of a decedent who died intestate. In the course of her examination, Professor Ronner not only dissected the flaws in the court opinions but also discussed how the tone and content of the decisions create a legal atmosphere that encouraged same-sex couples to remain closeted-with all of the negative repercussions attendant to that societal construct. ${ }^{114}$

The question to explore with regard to both attorneys and judges is how their perspectives and preconceptions influence their representation of LGBT clients and the decisions that they make affecting LGBT individuals and their (chosen) family members. Once this question has been answered, it will be important to consider whether it is possible (and, if so, how) to train current and future estate planning attorneys and judges to be sensitive to the various and differing needs of clients in nontraditional family arrangements, so as to respect their autonomy and choices.

To educate elder law professionals, Professor Nancy Knauer has helpfully written about the unique experiences of the pre-Stonewall generation of LGBT elders. ${ }^{115}$ For example, in "Gen Silent": Advocating for LGBT Elders, Professor Knauer not only described the unique experiences that have shaped the worldview of this generation of LGBT elders, but also how estate planning can be used to help protect them and

\footnotetext{
${ }^{112}$ Amy D. Ronner, Homophobia: In the Closet and in the Coffin, 21 LAW \& INEQ. 65 (2003).

113994 P.2d 240 (Wash. Ct. App. 2000), reversed and vacated by 33 P.3d 735 (Wash. 2000).

${ }^{114} I d$. at $68-74,85-111$.

${ }^{115}$ E.g., Nancy J. Knauer, “Gen Silent”: Advocating for LGBT Elders, 19 ELDER L.J. 289 (2012).
} 
improve their lives. In an ever-changing legal and social landscape, this work will need to be revisited and renewed as each post-Stonewall generations ages. As described above, it is important not only to educate elder law professionals (and judges) about their LGBT clients but also to educate them about themselves-identifying conscious and unconscious biases among these professionals that might influence the advice and assistance that they provide to LGBT elders.

\section{SOCIOECONOMIC CLASS}

In view of the role that the law of wills, trusts, and estates plays in perpetuating the concentration of wealth and reifying the privilege of a wealthy few, one would expect that an examination of this area through the lens of socioeconomic class would be a natural starting point for critical analysis. Surprisingly, however, there is a paucity of work exploring the class-based aspects of the law of wills, trusts, and estates.

Among the work that does examine this area from a class-based perspective, Professor Stephen Clowney's In Their Own Hand: An Analysis of Holographic Wills and Homemade Willmaking discusses the results of an empirical study of holographic wills undertaken in Pennsylvania. ${ }^{116}$ To test the conventional wisdom that holographic wills are open to fraud, invite litigation, and are fraught with errors, Professor Clowney reviewed all of the holographic wills filed in Allegheny County during two separate years. He showed that women disproportionately executed holographic wills, that the testators came from a variety of socioeconomic backgrounds, and that the holographic wills were no more likely to be challenged than formally executed wills. ${ }^{117}$ Many of the holographic wills did, however, contain drafting errors or lacunae. ${ }^{118}$ Based on the results of his study, Professor Clowney argued that states should permit testators to draft holographic wills and should similarly reduce the formalities required to execute a will. ${ }^{119}$

Although this study was not aimed specifically at addressing issues of socioeconomic class, Professor Clowney did note the class-based implications of his study. By permitting testators to draft their own wills, he contended that states would reduce the financial obstacles that those with low income encounter when setting forth their intentions regarding how their property should be distributed at death. ${ }^{120}$ Because the

116 Stephen Clowney, In Their Own Hand: An Analysis of Holographic Wills and Homemade Willmaking, 43 REAL PROP. TR. \& EST. L.J. 27 (2008).

${ }^{117}$ Id. at 43-47, 59-61.

${ }^{118}$ Id. at 47-52.

${ }^{119} \mathrm{Id}$. at $62-70$.

${ }^{120} \mathrm{Id}$. at 53-58. 
likelihood that a testator will not have a will is inversely related to the testator's income level, permitting the probate of holographic wills would help to ensure that low-income testators pass their property as they intend-rather than having those intentions presumed by state intestacy laws. $^{121}$

Professor Reid Weisbord took these proposals a step further in his article In Their Own Hand: An Analysis of Holographic Wills and Homemade Willmaking. ${ }^{122}$ In that article, Professor Weisbord put forth a new twist on old proposals to enhance the accessibility of testation through the creation of a statutory form will. His innovations included redrafting the residuary clause into plain English and moving it to the beginning of the form - as a designation of the primary beneficiaries of the will (i.e., those who will take all property for which a specific designation is not later made in the will). ${ }^{123}$ In addition, Professor Weisbord would make the form available as a schedule to the state income tax return, provide computer-aided drafting assistance, dispense with separate formalities of execution (employing instead the formalities that typically attend the electronic filing of income tax returns), and encourage the electronic filing of the will for storage by the state until the time of probate. $^{124}$

Future research could, of course, continue exploring ways of reducing the obstacles that low- and middle-income testators encounter when attempting to create an estate plan. For instance, commentators could helpfully explore the ways in which the bar or the state might educate testators about the law of wills, trusts, and estates either to make them better consumers of legal services when they seek the aid of a lawyer or to reduce errors in the drafting of wills when they do not. But it would also be interesting to see commentators probe the role that the law of wills, trusts, and estates plays in reifying privilege - not to mention seeing them consider ways in which this area of law might be used to chip away at that privilege or to aid those who do not find themselves endowed with a great deal of property to actually accumulate some property that they might someday pass to their heirs.

It is usually at a different point of intersection that discussions of chipping away at the privilege of the wealthy occurs; namely, at the intersection of the law of wills, trusts, and estates with the tax system. Discussions of the redistributive potential of the estate tax seem to surface

${ }^{121} I d$. at 64 .

${ }^{122}$ Reid Kress Weisbord, Wills for Everyone: Helping Individuals Opt Out of Intestacy, 53 B.C. L. REV. 877 (2012).

${ }^{123}$ Id. at $927-28$.

${ }^{124} \mathrm{Id}$. at $928-32$. 
when the country faces large deficits and needs to address the national debt. Some twenty years ago in his article Curtailing Inherited Wealth, Professor Mark Ascher proposed curtailing inheritance through changes to the estate and gift taxes, with the goal of increasing equality of opportunity and reducing the deficit. ${ }^{125}$ Aside from a reduced (but still generous) universal exemption, Professor Ascher would only permit limited transfers at death free of a confiscatory (i.e., 100\%) estate tax; that is, he would permit tax-free transfers to those who helped to create the wealth (e.g., spouses), to those who depend upon the decedent for their care (e.g., dependent children, disabled descendants, and parents and grandparents of the decedent), and to charity. ${ }^{126}$ Professor Ascher also suggested correlative changes to the gift tax in keeping with his proposal and to backstop the revised estate tax regime. ${ }^{127}$

More recently, in Occupy the Tax Code: Using the Estate Tax to Reduce Inequality and Spur Economic Growth, Professors Paul Caron and James Repetti argued that decreasing the estate tax exemption and increasing the top estate tax rate would be a salutary means of reducing inequality in the United States. ${ }^{128}$ Professors Caron and Repetti summarized data on the increase in income and wealth inequality in the United States as well as studies on the role of the tax laws in reducing inequality. ${ }^{129}$ After considering the inconclusive data on the (in)efficiency of the estate tax, Professors Caron and Repetti argued that the estate tax is an efficient means to reducing inequality because " $[\mathrm{t}]$ here is a strong theoretical argument that the estate tax should have much less of an impact on savings than the income tax because of our psychological tendency to deny death and because the expected value of the estate tax's effective rate is small during the period of life that taxpayers are creating wealth.", 130

Given the benefits of earmarking tax revenue, ${ }^{131}$ an area that might fruitfully be explored is the idea of a negative inheritance tax. In other words, scholars might explore the possibility of tying direct or tax expenditure programs that aim to redress socioeconomic (or even other forms of) inequality to the revenue raised by the estate tax, in lieu of advocating an increase in the estate tax as an efficient way to raise revenue for general spending or deficit reduction. Such proposals might not only

\footnotetext{
${ }^{125}$ Mark L. Ascher, Curtailing Inherited Wealth, 89 MICH. L. REV. 69 (1990).

${ }^{126}$ Id. at $121-36$.

${ }^{127}$ Id. at $137-50$.

${ }^{128}$ Paul L. Caron \& James R. Repetti, Occupy the Tax Code: Using the Estate Tax to Reduce Inequality and Spur Economic Growth, 40 PEPP. L. REV. 1255 (2013).

${ }^{129} I d$. at $1257-80$.

${ }^{130} \mathrm{Id}$. at 1288; see id. at 1280-88 (discussing the data).

${ }^{131}$ See generally Susannah Camic, Earmarking: The Potential Benefits, 4 PITT. TAX REV. 55 (2006).
} 
make the estate tax more palatable, but also might make programs designed to reduce inequality themselves more palatable and politically understandable to the population at large

\section{DisABILITY}

Issues relating to disability arise in many areas of the law of wills, trusts, and estates. Focusing on special needs trusts in his article Supplemental Needs Trust for People with Disabilities: The Development of a Private Trust in the Public Interest, Professor Joseph Rosenberg traced the origins of trusts to their use as a vehicle to avoid rigidity in English law and to alleviate the economic hardship of those who might otherwise be disadvantaged under the law. ${ }^{132}$ Professor Rosenberg then described the evolution of the special needs trust, which is a trust designed to simultaneously avoid the beneficiary's disqualification from government assistance and allow monies to be spent to enhance the quality of life of the disabled beneficiary by defraying expenses not covered by government assistance. ${ }^{133}$ Furthermore, Professor Rosenberg emphasized how, as sanctioned by Congress, a pooled special needs trust takes the rare step of "redistribut[ing] wealth away from the government and toward nonprofit groups that serve indigent individuals with severe disabilities." 134

Given the benefits of special needs trusts and the protections Congress intended to afford them, Professor Rosenberg critiqued a line of cases concerning the priority of Medicaid liens. According to Professor Rosenberg, this line of cases violates the intent of Congress in carving special needs trusts out of the resources that are taken into account in determining eligibility for Medicaid by allowing states to seize money judgments rendered against tortfeasors who caused the individual to seek government assistance in the first place. ${ }^{135}$ Professor Rosenberg put forth a number of proposals for improving these congressionally authorized special needs trusts, including a proposal to defer enforcing Medicaid liens until the death of the beneficiary of the special needs trust. ${ }^{136}$ Given that special needs trusts can "create opportunities for independent living, innovative rehabilitation and therapy, employment, and other activities that give life meaning," Professor Rosenberg concluded by asserting that

\footnotetext{
132 Joseph A. Rosenberg, Supplemental Needs Trust for People with Disabilities: The Development of a Private Trust in the Public Interest, 10 B.U. PUB. InT. L.J. 91, 99-103 (2000).

${ }^{133} I d$. at $147-48$.

${ }^{134} I d$. at 132 ; see id. at 110-36 (describing development of special needs trusts).

${ }^{135} \mathrm{Id}$. at $136-44$.

${ }^{136} I d$. at $149-51$.
} 
"[t]he concept of the supplemental needs trust should be strengthened, replicated, and expanded.",137

While Professor Rosenberg focuses on the ability of the law of trusts to enhance the quality of life of disabled individuals, there is a shadow lurking behind this positive story that bears consideration: the role of paternalism in representing or dealing with disabled individuals. ${ }^{138}$ Consideration should be given to the agency costs of using a trust as the vehicle for enhancing a disabled individual's quality of life. By necessity, the use of a trust places funds in the hands of someone other than the disabled individual to enhance the disabled individual's quality of life - as the trustee deems appropriate. This strips the disabled individual of the ability to freely make choices for herself regarding what spending will enhance her quality of life. Some thought should be given to developing reform proposals that restore this agency and both hear and respect the wishes of the individual whose life society is purporting to improve through the creation and sanctioning of special needs trusts.

As part of a faculty day presentation at New York Law School, Professor Pamela Champine penned an essay titled A Sanist Will?, in which she brought "the theoretical construct of sanism from the areas of civil commitment and criminal law, in which it was developed, to the law of wills." 139 Professor Champine suggested that sanism - the "irrational prejudice against or judgment about persons with mental disabilities" - is a potential explanation for the discrimination in the application of the doctrine of testamentary capacity against those who make dispositions of property that fail to conform to societal expectations. ${ }^{140}$ After searching for signs of sanism in the policy underlying the doctrine of testamentary capacity and in the case law applying it, ${ }^{141}$ Professor Champine discussed

several beneficial corollaries to the reduction of sanism, including reduction of discrimination in testamentary validity based upon failure to comport with societal norms; renewed focus on the extent to which family protection is desired and desirable; potential enhancement of therapeutic consequences for testators and those involved in will contests; and integration of ethical concerns faced by estate planning lawyers who serve clients of questionable capacity into the law of testamentary capacity. ${ }^{142}$

${ }^{137}$ Id. at 151 .

138 See generally Stanley S. Herr, Representation of Clients with Disabilities: Issues of Ethics and Control, 17 N.Y.U. REV. L. \& Soc. CHANGE 609 (1989-1990).

${ }^{139}$ Pamela R. Champine, A Sanist Will?, 46 N.Y.L. ScH. L. REV. 547, 549 (2003).

${ }^{140} \mathrm{Id}$. at 548 .

${ }^{141} I d$. at $549-56$.

${ }^{142}$ Id. at 548; see id. at 556-64. 
Responding to Professor Champine's work, two students made contributions to faculty day on the topic of sanism in the law of wills, trusts, and estates. In keeping with Professor Champine's contribution, Heather Ellis argued in favor of "raising the bar to a stricter standard of scrutinizing the mental capacity of the aged or disabled." ${ }^{143}$ Ms. Ellis urged probing the operation of the test for testamentary capacity in practice, with the aim of ensuring that it does not mask illness or incorrectly label someone as lacking testamentary capacity. ${ }^{144}$ In particular, Ms. Ellis drew attention to the intersection of sanism and paternalism with socioeconomic class. Ms. Ellis noted that

[s]omeone of high social status with greater economic resources has a much better chance of probating a will even though the will has eccentricities or leaves out close relatives. Sanism in how we view people's economic status in society will draw a fine line between being eccentric and being mentally ill or incompetent. ${ }^{145}$

Those with wealth and power are, from a sanist perspective, both less likely to be perceived as mentally ill or incompetent and are more likely to have the means to defend against allegations of incapacity. ${ }^{146}$

Claire Steinberger examined and summarized Professor Champine's work, underscoring the possibility that the probate process and determinations of testamentary capacity might simultaneously be skewed by and reify cultural norms. ${ }^{147}$ This is an area worthy of further exploration, as it sits at the intersection of disability with gender, race, class, gender identity/expression, and sexual orientation. Individuals in all of these groups may be the victim of hidden (or not so hidden) biases that are used to force behavior to conform to majoritarian expectations. A holistic view that brings together all of these different perspectives might help to formulate better, more comprehensive proposals that combat these biases, increase the respect for the individual in a pluralistic society, and have a greater likelihood of adoption.

\footnotetext{
${ }^{143}$ Heather S. Ellis, Note, "Strengthen the Things That Remain": The Sanist Will, 46 N.Y.L. SCH. L. REV. 565, 566 (2003).

${ }^{144}$ Id. at $567-68$.

${ }^{145} \mathrm{Id}$. at 569.

${ }^{146}$ See id. at 569-70 (citing Seward Johnson as an example).

147 Claire B. Steinberger, Note, Therapeutic Jurisprudence: The "Sanist" Factor-An Interdisciplinary Approach, 46 N.Y.L. Sch. L. Rev. 573, 576-79.
} 


\section{CONCLUSION}

Disposing of one's property during lifetime and at death is an individual and private matter. The structure of the law of wills, trusts and estates is designed to safeguard and effectuate decisions made by individuals. But inheritance is not only a private matter. It is "a public event with symbolic messages about normative property distribution, individual freedom, and familial or other collective obligations." ${ }^{\prime 48}$ These symbolic messages cannot be ignored. Scholars need to continuously engage with them, along with the structure and mechanisms of the law that underpin those symbolic messages. Law not only effectuates individual intent regarding the disposition of property, but also functions as structure itself that must be evaluated for bias.

The law in action needs to fulfill its aspirational commitments. This is as much true for "money law" as it is for other areas-and perhaps more so. Without the ability to accumulate wealth and pass it from generation to generation, historically disempowered groups may find themselves trapped as the avenues for advancement - what some might call the American promise of a better life for each "next" generation-are closed off from them. Cutting off any group from this societal aspiration affects us all, because it inhibits the flourishing of our society. In this way, how well any area of law safeguards the historically disadvantaged is a measure of equality and justice for all people

${ }^{148}$ Hacker, supra note 55, at 323. 